\title{
A SURVEY FOR MAINTENANCE OF VIRULENT NEWCASTLE DISEASE VIRUS-FREE AREA IN POULTRY PRODUCTION IN BRAZIL
}

\author{
Orsi, M.A. ${ }^{1,2}$; Doretto Jr, L. ${ }^{3}$; Camillo, S.C.A. ${ }^{1}$; Reischak, D. ${ }^{1}$; Ribeiro, S.A.M. ${ }^{1}$; Ramazzoti, A. ${ }^{1}$; Mendonça, A.O. ${ }^{1}$; \\ Spilki, F.R. ${ }^{4}$; Buzinaro, M.G. ${ }^{5}$; Ferreira, H.L. ${ }^{6}$; Arns, C.W. ${ }^{2,6^{*}}$
}

${ }^{1}$ Laboratório Nacional Agropecuário, Ministério da Agricultura, Pecuária e Abastecimento, Campinas, SP, Brasil; ${ }^{2}$ Faculdade de Ciências Médicas, Universidade Estadual de Campinas, Campinas, SP, Brasil; ${ }^{3}$ Centro Brasileiro de Pesquisa Animal, Amparo, SP, Brasil; ${ }^{4}$ Instituto de Ciências da Saúde, Centro Universitário Feevale, Novo Hamburgo, RS, Brasil; ${ }^{5}$ Departamento de Medicina Veterinária Preventiva e Reprodução Animal, Faculdade de Ciências Agrárias e Veterinárias, Universidade Estadual Paulista, Jaboticabal, SP, Brasil ${ }^{6 *}$ Laboratório de Virologia, Instituto de Biologia, Universidade Estadual de Campinas, Campinas, SP, Brasil.

Submitted: February 03, 2009; Returned to authors for corrections: March 16, 2009; Approved: February 17, 2010.

\begin{abstract}
In 2003, Brazil was recognized as a pathogenic Newcastle Disease Virus (NDV) strain-free country for commercial poultry. This research was conducted in Brazil between December 2003 and March 2005 to verify the maintenance of this virulent NDV-free status. Serum samples from 5,455 flocks for commercial poultry farms were collected, comprising 81,825 broiler chickens. The farms were located in nine states of the country, grouped in three geographic regions. Serological evidence of NDV infection was detected in $28.8 \%$ of the surveyed farms. However, all fifteen viruses isolated and identified as Newcastle Disease Virus (NDV) were characterized as nonpathogenic strains, based on the Intracerebral Pathogenicity Index. These results showed that Brazil preserves the virulent NDV-free status for commercial flocks.
\end{abstract}

Key words: Newcastle Disease Virus, pathogenicity, poultry, biological characterization.

\section{INTRODUCTION}

Newcastle disease virus (NDV) is a negative-stranded RNA virus of the Avulavirus genus within the Paramyxoviridae family of the Mononegavirales order $(17,18)$. NDV is also referred to as avian paramyxovirus-1 (APMV-1), one of the nine identified paramyxovirus serotypes known to infect birds, representing one of the most important threats to the poultry industry. Infection in birds can be acute, chronic or asymptomatic and may affect wild and domestic birds, a significant source of protein in developing countries (14). Newcastle Disease (ND) is frequently responsible for devastating losses in poultry production. Spradbrow (23) estimated that in Nepal $90 \%$ of poultry dies each year as a result of this disease. NDV infection in poultry ranges from unapparent to rapidly fatal, depending on the virus pathotype (6). Therefore, the ethiopathogenic diagnosis should be based on isolation and biological characterization of field samples (26). Nowadays, the disease has a worldwide distribution with a large rank of hosts. Alexander (3) reported that natural or 
experimental infection comprises over 250 different bird species, although many existing species have never yet been diagnosed. The widespread presence of lentogenic strains in feral birds and the use of such viruses as live vaccines mean that the isolation of NDV is not enough to confirm a disease diagnosis. For confirmation the virus needs to be characterized by pathogenicity tests or nucleotide sequencing. The importance and impact of a given NDV isolate are directly related to the virulence of the viral strain. As field investigation of the disease can be an unreliable measure, laboratory assessment of the virus pathogenicity by the determination of the Intracerebral Pathogenicity Index (ICPI) in day-old chicks Gallus gallus should be done. The World Organization for Animal Health-OIE (30) defines ND as a notifiable disease when the virus has an ICPI of 0.7 or above or presents multiple basic amino acids at the F protein cleavage site. An APMV-1 virus which does not meet the OIE definition for causing ND is referred to as a low-virulence APMV-1 or NDV.

In 2003, Brazil was recognized as a country free of pathogenic NDV strains in commercial poultry $(19,31)$. However, despite the rigorous biosecurity measures adopted by the poultry industry, the risk of reintroduction of viruses into domestic poultry is always present. The present work was conducted to verify whether Brazil maintains the non-virulent Newcastle disease status for commercial flocks.

\section{MATERIALS AND METHODS}

\section{Sample calculations and sources}

Samples were collected weekly during seven consecutive production cycles of birds in slaughterhouses located in selected areas of nine states of the Southeastern, Southern and Central Western regions of Brazil, corresponding to those where the Brazilian poultry industry is concentrated. Blood serum of 15 birds per flock and pools of eight tracheas and eight cloacae swabs were placed separately in a buffered saline solution (PBS) with antibiotics $(10,000 \mathrm{U} / \mathrm{ml}$ penicillin, 10 $\mathrm{mg} / \mathrm{ml}$ streptomycin, $0.25 \mathrm{mg} / \mathrm{ml}$ gentamicin and 5,000 IU/ml nystatin), adjusted to $\mathrm{pH}$ 7.0-7.4, and cold-stored.
Collected samples were sent to a screening centre in each state to ensure analysis viability, and insertion of data into an computerized information system. The material was sealed up and sent in the thermal ice boxes to the National Agricultural Laboratory (Lanagro/SP) in Campinas, São Paulo, Brazil.

The calculation of the number of samples for the study was based on the total population of birds in each federative state, from a total of $410,729,182$ birds in the country, according to the Brazilian Ministry of Agriculture. Federative states were selected based on their importance for the Brazilian poultry industry, and comprised three regions: Southeastern (Minas Gerais and São Paulo states) Southern (Paraná, Santa Catarina and Rio Grande do Sul states) and Central Western (Goiás, Distrito Federal, Mato Grosso and Mato Grosso do Sul states).

The number of samples in each region was calculated using the following formula:

[1- (1-C) 1/(D*SENS)]* [M- (/2 D*SENS-1)], where:

$\mathrm{C}=$ Reliable degree

$\mathrm{M}=\mathrm{n}$. of units (animal/flocks) at risk

$\mathrm{D}=\mathrm{n}$. of ill/infected units

SENS $=$ Sensitivity test

The calculated number of samples was 81,825 broiler chickens, being 27,165 birds in 1,811 farms of the Southeastern region, 28,905 birds of 1,927 farms in the Southern region and 25,755 birds of 1,717 farms in the Central Western region.

\section{Detection of NDV antibodies}

Chicken serum samples were diluted 1:500 and examined for NDV antibodies by indirect enzyme-linked immunosorbent assay (ELISA), using a commercial ELISA test kit (Flockscreen - Guildhay Laboratories Inc., Guilford, England), run in 96-well microtiter plates containing NDV antigen. The ELISA test was performed according to the manufacturer's recommendations. When at least one bird from a flock was ELISA positive, the whole flock was considered positive.

\section{Virus isolation}

Cloacal and tracheal swabs from all ELISA seropositive 
birds and from $30.3 \%$ of ELISA seronegative birds were submitted to isolation of virus. The swabs, stored in transport media composed of phosphate-buffered saline solution (PBS) containing antibiotics, were sent to the National Agricultural Laboratory (Lanagro/SP), Campinas, São Paulo within 48 hrs after collection, in a refrigerated container $\left(2-8^{\circ} \mathrm{C}\right)$. In the laboratory the samples were stored at $-80^{\circ} \mathrm{C}$ until analyzed. The swabs were pooled and inoculated into five specificpathogen-free embryonated chicken eggs (9-11 days old), and processed according to standard NDV isolation procedures described by Alexander et al. (4) and by the Regulation \#182/94 of the Brazilian Ministry of Agriculture (13). The samples were submitted to three trials in embryonated chicken eggs, before considered negative.

\section{Virus identification}

NDV was identified using reference antisera APMV-1 to APMV-9 by the haemagglutination inhibition (HI) test, carried out according to Alexander (2) and Regulation \# 182/94 of the Brazilian Ministry of Agriculture (13). APMV-5 was not used in the analyses as it does not produce haemagglutination. Antisera were produced by the Veterinary Laboratory Agency (VLA) in Weybridge, Surrey, United Kingdom.

\section{Biological pathotyping of the NDV}

Pathotyping was based on measurement of the Intracerebral Pathogenicity Index (ICPI) in one day-old chicks from specific-pathogen-free (SPF) parents. In the ICPI test, birds are inoculated intracerebrally and then examined every day for eight days. The birds are scored at each observation: 0if normal, 1- if sick and 2- if dead. The ICPI is the mean score per bird per observation over the eight-day period. According to the World Organization for Animal Health-OIE (30) an isolate with an ICPI $\geq 0.70$ should be classified as pathogenic, and the ICPI for live vaccines should not exceed 0.4 (14). These guidelines have also been adopted by OIE (27). ICPI was determined following procedures of the World Organization for Animal Health (30) and the Regulation 182/94 of the Brazilian Ministry of Agriculture (13).

\section{Statistical analysis}

Statistical analysis was performed using the Chi-Square or Fisher's Exact test (25). Differences were considered statistically significant when $\mathrm{p} \leq 0.05$.

\section{RESULTS}

The serology and virus isolation results are shown in Table 1. The highest prevalence of seropositive samples occurred in Southeastern region (44.8\%), followed by Southern (23\%) and Central Western regions $(18.3 \%)$. In the country, the prevalence was $28.8 \%$. The average percentage of isolation per flock was $0.27 \%$, being $0.44 \%$ in the Southeastern region, $0.23 \%$ in the Central Western region and $0.15 \%$ in the Southern region. There was a significant difference in the percentage of seropositive samples in the three regions $(\mathrm{p}<$ 0.0001). The Southeastern region presented the highest percentage when compared to the other regions.

Table 1. Relationship between NDV-seropositivity and NDV isolation

\begin{tabular}{|c|c|c|c|c|c|c|c|}
\hline \multirow[b]{2}{*}{ Region } & \multirow[b]{2}{*}{$\begin{array}{c}\text { Flocks } \\
\text { (n) }\end{array}$} & \multirow[b]{2}{*}{$\begin{array}{c}\text { Birds } \\
\text { (n) }\end{array}$} & \multirow{2}{*}{$\begin{array}{c}\text { ELISA } \\
\text { seropositive } \\
\text { flocks \% }\end{array}$} & \multicolumn{4}{|c|}{ NDV isolation } \\
\hline & & & & (n) & $\begin{array}{c}\text { ELISA } \\
\text { positive \% }\end{array}$ & $\begin{array}{c}\text { Flocks } \\
\%\end{array}$ & $\begin{array}{c}\text { Region } \\
\%\end{array}$ \\
\hline Southeastern & 1,811 & 27,165 & $812(44.8)^{*}$ & 08 & 1.0 & 0.44 & 53.3 \\
\hline Southern & 1,927 & 28,905 & $444(23,0)$ & 03 & 0.4 & 0.15 & 20.0 \\
\hline Central Western & 1,717 & 25,755 & $315(18.3)$ & 04 & 0.9 & 0.23 & 26.7 \\
\hline TOTAL & 5,455 & 81,825 & $1,571(28.8)$ & 15 & 0.8 & 0.27 & 100.0 \\
\hline
\end{tabular}

*The percentage of seropositive flocks in the Southeastern region was significantly higher than that in the other two regions $(\mathrm{p}<0.05)$. 
The NDV isolation percentages in ELISA positive flocks by region were $1.0 \%, 0.9 \%$ and $0.4 \%$ in Southeastern, Central Western region and Southern regions, respectively. Considering the total number of isolates, $53.3 \%$ of the flocks were from the Southeastern region, $26.7 \%$ from the Central Western region and $20.0 \%$ from the Southern region.

The states with higher viral isolation percentage per flock were São Paulo (0.58\%) and Mato Grosso do Sul (0.50\%), followed by Rio Grande do Sul (0.37\%), Minas Gerais (0.16\%) and Paraná $(0.14 \%)$, as shown in Table 2. Among isolates, 46.7\% were from São Paulo state, 26.7\% from Mato Grosso do Sul state, $13.3 \%$ from Rio Grande do Sul state and 6,7\% from Minas Gerais and Paraná states. Four states (Mato Grosso, Distrito Federal, Goiás and Santa Catarina) did not present any viral isolate. Figure 1 shows the isolation of NDV by geographic region.

Table 2. Percentage of NDV positive flocks according to region and state

\begin{tabular}{ccccc}
\hline Region & States & $\begin{array}{c}\text { Number of } \\
\text { flocks } \\
\text { surveyed }\end{array}$ & $\begin{array}{c}\text { ELISA } \\
\text { positive } \\
\text { flocks } \\
(\boldsymbol{\%})\end{array}$ & $\begin{array}{c}\text { Isolation } \\
\text { positive flocks } \\
(\%)\end{array}$ \\
\hline \multirow{2}{*}{ Southeastern } & Minas Gerais & 620 & 0.16 & 6.7 \\
Central Western & São Paulo & 1,191 & 0.58 & 46.7 \\
Sato Grosso do Sul & 796 & 0.50 & 26.7 \\
& Paraná & 688 & 0.14 & 6.7 \\
\hline
\end{tabular}

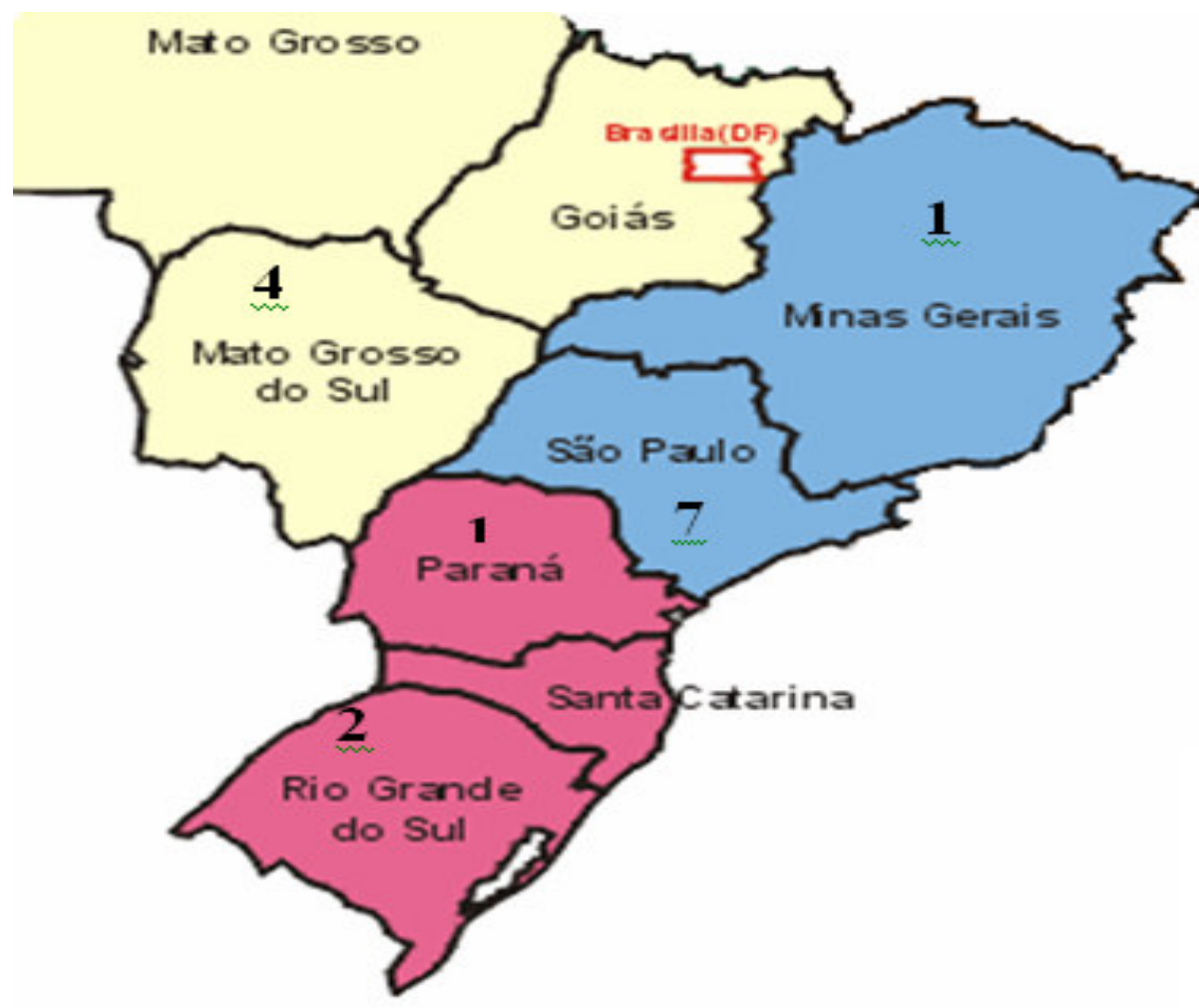

Figure 1. Number of Newcastle Disease Virus isolates according to the geographic region (number of isolates in black) 
In the characterization of pathogenic NDV isolates (Table 3 ), the ICPI ranged between 0.0 and 0.47 . In $53.3 \%$ of the NDV isolates, ICPI varied from 0 to 0.10 , and in $26.6 \%$ varied from 0.11 to 0.30 . In $20 \%$ of the isolates, the ICPI values varied from 0.31 to 0.47 . These data indicate that none of the isolates was pathogenic, as their ICPI was lower than 0.70 .

The grouping of the viruses by ICPI and region is shown in the Table 4. The ICPI of vaccinal strains is also shown in Table 4 for comparison. The $1^{\text {st }}$ group, with $53.3 \%$ of the isolates, presented ICPI 0.0 to 0.10 , similar to vaccinal strains
Ulster, VG-GA, V4 and C2. The isolates in the $1^{\text {st }}$ group were mainly from Southeastern and Central Western regions $(37.5 \%)$ followed by Southern region $(25 \%)$. The $2^{\text {nd }}$ group, represented by B1 strain (ICPI from 0.11 to 0.30 ), comprised $26.6 \%$ of the NDV isolates $-75 \%$ in the Southeastern and $25 \%$ in the Central Western regions. The $3^{\text {rd }}$ group represented by $\mathrm{La}$ Sota and Clone 30 strains, comprised $20 \%$ of isolates (ICPI0.31 to 0.47$)-66.6 \%$ in the Southeastern and $33.4 \%$ in the Southern regions.

Table 3. Intracerebral pathogenicity index (ICPI) of NDV isolates

\begin{tabular}{|c|c|c|c|}
\hline Region & Vaccination & Number of isolates & Range of ICPI \\
\hline \multirow{3}{*}{ Southeastern } & + & 03 & $0-0.1$ \\
\hline & + & 02 & $0.11-0.30$ \\
\hline & + & 01 & 0.47 \\
\hline \multirow{2}{*}{ Southeastern } & - & 01 & 0.15 \\
\hline & - & 01 & 0.42 \\
\hline \multirow[b]{2}{*}{ Southern } & - & 02 & $0-0.1$ \\
\hline & - & 01 & 0.36 \\
\hline \multirow{2}{*}{ Central West } & - & 03 & $0-0.1$ \\
\hline & - & 01 & 0.14 \\
\hline Total & & 15 & \\
\hline
\end{tabular}

Table 4. Grouping of the NDV isolates and Vaccinal Strains by ICPI

\begin{tabular}{cccccc}
\hline Group & Range of ICPI & $\begin{array}{c}\text { Number of } \\
\text { isolates }\end{array}$ & NDV \% & Region \% & Vaccinal Strain \\
\hline & & & & $37.5 \mathrm{ST}$ & Ulster, VG-GA, \\
$(1)$ & 0.00 to 0.10 & 8 & 53.3 & $\begin{array}{c}37.5 \mathrm{CW} \\
25 \mathrm{~S}\end{array}$ & V4, C2 \\
& & & & $75 \mathrm{ST}$ & $\mathrm{B}_{1}$ \\
$(2)$ & 0.11 to 0.30 & 4 & 26.6 & $25 \mathrm{CW}$ & \\
& & & & $66.6 \mathrm{ST}$ & La Sota, Clone 30 \\
\hline
\end{tabular}




\section{DISCUSSION}

The present study confirms results of a previous report indicating that poultry in the Southeastern region of Brazil is vaccinated against NDV (19), although there are flocks of this region with no information about vaccination. In addition, in the Northern part of state of Paraná, all categories of commercial poultry were vaccinated against Newcastle disease, leading to a large number of serology positive samples in this state. On the other hand, the present study demonstrated that NDV was circulating in regions with no information on vaccination. An important point to consider is the "spreadability" of the live vaccines, given their capacity to immunize individuals other than those individually vaccinated (11). The risk factors associated with seropositive NDV were identified by East et al. (16), who demonstrated that age of the flock, proximity to neighbor poultry farms and location of the farm (either in increase Sydney Basin or Eastern Victoria, Australia) were the most important. Several other risk factors in the slaughterhouse were postulated: security level, sanitation of chicken water supply and exclusion of wild and free range birds from chicken housing $(12,16,25)$. The risk of seropositive NDV may be attributed to the occurrence and frequency of breaches in security and hygiene rather than to the adopted levels of biosecurity and hygiene (15).

Results show that vaccination against ND in broiler chicken does not occur in the states of Rio Grande do Sul, Santa Catarina, Mato Grosso, Mato Grosso do Sul and Goiás, nor in the Federal District. However, it is known that in these states, birds are vaccinated only when used for long-life purposes, such as egg production.

In this study, NDV was isolated from healthy birds in a frequency varying from $0.15 \%$ to $0.44 \%$ per flock. The isolation varied from 20.0 to $53.3 \%$ according to the geographic region. In a previous study, Orsi et al (19) reported a higher frequency of 1.0 to $7.6 \%$ per flock, varying from $6.5 \%$ to $58.4 \%$ according to the geographic region. The isolation was higher in regions where vaccination was widely used. These data are in accordance with Alexander and Gough (6), who suggested that the vaccine protects birds from clinical diseases but replication and virus excretion may still occur, even in lower levels.

The decrease in the number of NDV isolation is evident when results are compared to those reported by Orsi et al (19). This decrease in positivity may be attributed to improvements in biosecurity and prohibition of transit of people in farms given the fear/preoccupation caused by avian influenza during this period. Between 2002 and 2005, several outbreaks of influenza virus were extensively reported in the world through the newspapers, TV and OIE communications, leading towards a change in posture and better control of the Newcastle disease virus in Brazil.

A serological study was also conducted in Benin, Africa, in three ecologically different regions (Southern, Central and Northern regions), and $56 \%, 75 \%$ and $69 \%$ of the chickens were seropositive, respectively $(9 ; 10)$. The African results were higher than those obtained in Brazil. Litter reuse observed in most regions can explain the presence of the virus as early as the first week of life of the bird, leading to the stimulation of the immune system.

The highest virus isolation in Southeastern region in Brazil, followed by the Central Western and Southern regions, were also reported in a previous study of Orsi et al (19), who detected more virus circulation in the Central Western region if compared to the Southern region. The more effective vaccination in the Southeastern area may correlate with the high number of isolates in this area. These results are in accordance with the history of vaccination, as a prevalence ranging from 5 to $29 \%$ was found in one small chicken flock and pure-bred poultry flocks (22).

Serological evidence and viral isolation in states that do not use vaccine against Newcastle Disease in broiler chickens can be explained by the high amount of birds in some regions, by the proximity with distinct categories of birds, and the coexistence low technology farms along with highly technified poultry farms.

The virus isolates in this study presented ICPI below 0.47 . This can be attributed to the most frequent use of vaccines B1 
and La Sota in Brazil, which present ICPI 0,2 and 0.4, respectively $(1,8)$. The World Organization for Animal Health (30) recommends that vaccine should have an ICPI below 0.7 , in order to meet the estimated interlaboratory variability and the required safety margin. Thus, the master seed of live vaccines should not present ICPI exceeding 0.4 (14).

Orsi et al. (20) verified that the ICPI values for all vaccines used in Brazil varied from 0 to 0.37 . The ICPI values of the isolates in this study are similar to those obtained for vaccines.

Yongolo (32), in Tanzania, also isolated lentogenic and mild virulent NDV from birds with clinical Newcastle disease, as well as from healthy carrier birds.

The results in the present study indicate that biosecurity measures associated with vaccination programs as postulated by the International Animal Health Code are crucial for the preservation of the virulent NDV-free status for industrial poultry in Brazil.

\section{ACKNOWLEDGMENTS}

Authors would like to thank the Brazilian Ministry of Agriculture for providing financial and technical resources, and authorization for publication this work coordinated by LANAGRO/SP. They also thank Cleide Aparecida Moreira Silva, from FCM/UNICAMP, for statistical analysis. C.W.A. and F.R.S. acknowledge the support from CNPq (National Council of Scientific and Technological Development, Brazil).

\section{REFERENCES}

1. Alexander, D.J.; Allan, W.H. (1974). Newcastle disease virus pathotypes. Avian Pathol; 3: 269-278

2. Alexander, D.J. (1992). Newcastle disease . OIE. Manual of standards for diagnostic test and vaccines. Paris. OIE.

3. Alexander, D.J. (1997). Disease of Poultry $10^{\text {th }}$ eds (Beard, B.W.; McDougauld, L.R.; Saif, Y.M (ed.). Iowa State University Press, Ames, Iowa, p.541-570.

4. Alexander, D.J. (1998). Newcastle disease and other avian Paramyxovirus. In: A Laboratory manual for the isolation and identification of avian pathogens 4th ed. D. Swayne, J.R. Glisson, M.W.
Jackwood, J.E. Pearson, and W. M. Reed, eds. American Association of Avian Pathologists, Kennett Square, PA. p. 156-163.

5. Alexander, D.J. (2001). Newcastle disease, Gordon Memorial Lecture. Newcastle disease. Br. Poult. Sci, 42(1): 5-22.

6. Alexander, D.J.; Gough, R.E. (2003) In: Diseases of poultry $11^{\text {th }} \mathrm{ed}$. (Saif, Y.M.; Barnes, H.J.; Fadly, A.M.; Glisson, J.R., McDougald, L.R. \& Swayne, D.E., eds), Iowa State University Press, Ames, Iowa, p.6399.

7. Alexander, D.J. (2004). Manual of diagnostic test and vaccines for terrestrial animals, 5th. ed. Office of International Des Epizooties, Paris, France, p. 270-282.

8. Allan, W.H.; Lancaster, J.E.; Toth, B. (1978). Newcastle disease vaccines. Their Production and Use. FAO Animal Production and Health Series $\mathrm{N}^{\circ}$ 10. FAO: Rome, Italy.

9. Bell, J.G. (1991). Vaccination of Africa village poultry against Newcastle disease. In: Demey and Pandey, V.S.(eds). Newcastle disease vaccination of village poultry in Africa and Asia. Proceedings of the seminar held on 13-14 February, Antwerp, p.3-8.

10. Bell, J.G. (1992). Newcastle disease in village chickens in North, West and Central Africa. In: Spradbrow, P.B. Ed., Newcastle Disease in Village chickens, Control with Thermo stable oral vaccines, Proceedings, International Workshop held in Kaula Lumpur, Malaysia, 6-10 October 1991. Centre for International Agriculture Research ACIAR, Canberra, p.142-143.

11. Bell, J.G. (2001). In: Proceedings of an international workshop, Maputo, Mozambique, 6-9. ACIAR Proceedings 103, (Alders R.G. and Spradbrow P.B. eds), Canberra, Australian, p. 56-60.

12. Bojeson, A.M.; Nielsen, S.S.; Bisgaard, M. (2003). Prevalence and transmission of Haemolytic Gallibacterium species in chicken production systems with different biosecurity levels. Avian Pathol. 32(5): 503-510.

13. BRASIL-Portaria Ministerial $\mathrm{n}^{\circ} 182$, de 8 de novembro de 1994. Aprova as Normas de Credenciamento e monitoramento de laboratórios de diagnóstico da doença de Newcastle. Diário Oficial da República do Brasil, Brasília, DF, 1994.

14. Council of the European Communities. (1993). Commission Decision of 8, February. Laying down the criteria to be used against Newcastle disease in the context of routine vaccination programmes. Off $J E u$. Commun; L59: 35.

15. East, I.; Kite, V.; Daniels, P.; Garner, G. (2006). A cross-sectional survey of Australian chicken farms to identify risk factors associated with seropositivity to Newcastle disease virus. Prev. Vet. Med. 77:199214.

16. Gibbens, J.C.; Pascoe, S.J.S.; Evans, S.J.; Davies, R.H.; Sayers, A.R. (2001). A trial of biosecurity as a means to control Campylobacter infection of broiler chickens. Prev. Vet. Med. 48: 85-99, 2001.

17. Mayo, M.A. (2002a). Virus taxonomy- Houston. Arch. Virol., 147, 107176.

18. Mayo, M.A. (2002b). A summary of taxonomic changes recently approved by ICTV. Arch. Virol., 147, 1655-1656. 
19. Orsi, M.A., Doretto Jr, L., Camillo, S.C.A., Reischak, D., Ribeiro, S.A.M., Ramazzoti, A., Mendonça, A.O., Spilki, F.R.; Buzinaro, M.G.; Arns, C.W. (2009a). Prevalence of Newcastle Disease Virus in broiler chickens (Gallus gallus) in Brazil. Braz J. Microbiol. 41(2), 349-357.

20. Orsi, M.A.; Doretto Jr, L.; Reischak, D.; da Silva, LHA.; Spilki, F.R.; Buzinaro, M. G.; Arns, C.W. (2009). Newcastle disease virus vaccine strains: Immunogenicity is not influenced by ICPI. Rev. Bras. Cienc. Avic. v.11, 2:129-133.

21. SAS System for windows (Statistical Analysis System), version 9.1.3 Service Pack 3. SAS Institute Inc, Cary, NC, USA. 2002-2003.

22. Schelling, E.; Thur. B.; Griot, C.; Audige, L. (1999). Epidemiological study of Newcastle disease in backyard poultry and wild bird populations in Switzerland.1999. Avian Pathol., 28(3):263-272.

23. Spradbrow, P.B. (1993). Newcastle disease in village chickens. Poultry Science Review, 5:57-96.

24. Spradbrow, P.B. (1992). Newcastle disease respite for poultry. Shell Agriculture, 12:29-31.

25. Tablante, N.L.; Myint, M.S.; Johnson, Y.J.; Rhodes, K.; Colby, M.; Hohenhaus, G. (2002). A survey of biosecurity practices as risk factors affecting broiler performance on the Delmarva Peninsula. Avian Dis.
46:730-734.

26. Vianna, J.S.M.; Mazur, C.; Portz, C.; Ferreira, II.; Almeida, C.A.S.; Galler, R. (2000). Identificação e caracterização biomolecular do vírus da doença de Newcastle pela técnica de RT-PCR. R. Bras. Med. Vet. 22(4): 30 .

27. World Organization for Animal Health - OIE (2000a). In: Manual of standards for Diagnostic Tests and Vaccines, 4th edition. World Organization for Animal Health, Paris, France, p.221-32.

28. World Organization for Animal Health - OIE (2000b). Report of the meeting of the OIE standards commission, November, OIE, Paris, 4.

29. World Organization for Animal Health - OIE (2007). Terrestrial Animal Health Standards Commission Report March 2007, APPENDIX 3.8.X. Guidelines on surveillance for Newcastle disease Article 3.8.X.1.

30. World Organization for Animal Health. (2008) In Manual of Diagnostic Tests and Vaccines for Terrestrial Animals, Chapter 2.3.14. p. 579-582.

31. World Trade Organization. Committee on Sanitary and Phytosanitary Measures, G/SPS/Gen/ 608, 08 December 2005.

32. Yongolo, M.G.S. (1996). Epidemiology of Newcastle Disease in Village Chickens in Tanzania. MVM. Dissertation, Sokoine University of Agriculture 230p. 